Puede citar este artículo como:

Viúla de Faria, Tiago. «Diplomacy in the Fifteenth-Century Monarchical State: A Baronial Pursuit? (Portugal, 1416-1449)». Anales de la Universidad de Alicante. Historia Medieval, N. 19 (2015-2016): 327-342, DOI:10.14198/medieval.2015-2016.19.11

\title{
DIPLOMACY IN THE FIFTEENTH-CENTURY MONARCHICAL STATE: A BARONIAL PURSUIT? (PORTUGAL, 1416-1449)*
}

\author{
Tiago Viúla de Faria** \\ Universidade Nova de Lisboa
}

\section{RESUMEN}

En 1438 Pedro, duque de Coimbra, era el segundo en la línea de sucesión al trono portugués. La muerte de su hermano mayor Duarte había dejado la corona vacante y Pedro, un poderoso magnate de mediana edad fue elegido como regente del hijo de Duarte, Alfonso, el niño de seis años sobre quien recaía el reinado. Primero como corregente y después en solitario, Pedro gobernó Portugal y sus élites durante una década marcada a veces por la satisfacción y a veces por la agitación, así como por las luchas cortesanas entre facciones aristocráticas. En 1449, entre acusaciones de lesa majestad y de favorecer a su propia persona, Pedro encontraría un amargo final en el campo de batalla, a manos de su joven sobrino, el rey Alfonso V, al parecer

\footnotetext{
Abbreviations used: AHMCML for the Arquivo Histórico Municipal da Câmara Municipal de Lisboa; TNA for The National Archives, Kew (London); TT for the Arquivo Nacional-Torre do Tombo (Lisbon).

** Affiliation: Instituto de Estudos Medievais (Faculdade de Ciências Sociais e Humanas, Universidade Nova de Lisboa); CITCEM (Universidade do Porto). FCT Research Fellow (co-funded by POPH-QREN/ESF: SFRH/BPD/94517/2013); Associate Researcher, Project DEGRUPE: «The European Dimension of a Group of Power: Ecclesiastics and the Political State Building of the Iberian Monarchies $\left(13^{\text {th }}-15^{\text {th }}\right.$ Centuries)» (co-funded by FCT/MEC, FEDER, COMPETE-POFC: PTDC/EPH-HIS/4964/2012). Maria João Branco, Hermenegildo Fernandes, Alice Santos, John Watts and especially the two anonymous reviewers of this article are to be thanked for their comments and suggestions.
} 
manipulado por una influente camarilla de enemigos del regente. El artículo examinará la actuación de Pedro de Coimbra y de algunos de sus hombres durante su carrera política (c. 1416-1449), particularmente la de aquellos empleados como «diplomáticos» en el extranjero. Se trazarán tres etapas diferentes en la trayectoria de Pedro -como infante, como consejero del rey y finalmente como regente del reino portugués- para conocer hasta qué punto un magnate destacado del siglo XV podía proyectar su influencia política en colaboración, o contra, el poder real. Finalmente, el artículo destaca la coexistencia, y también la superposición, entre las ambiciones diplomáticas reales y no reales y las tensiones y desafíos que causaban en la política y la diplomacia de Portugal durante dicho período.

Palabras clave: Diplomacia; Cultura política; Aristocracia; Portugal en la edad media; Soberanía.

\section{ABSTRACT}

In 1438 Pedro, Duke of Coimbra, was second-in-line to the Portuguese throne. The death of his elder brother Duarte had left the royal seat vacant and Pedro, a middle-aged, powerful magnate was elected as regent for Duarte's son Afonso, the boy of six to whom the crown fell. First as the coregent and then single-handedly, Pedro governed over Portugal and its elites during a decade marked in turn by contentment and upheaval, as much as by courtly struggles between aristocratic factions. In 1449, amidst accusations of lese-majesty and of favouring his own, Pedro would meet a bitter end in the field of battle, at the hands of his young nephew, King Afonso V, seemingly manipulated by an influential clique of enemies to the regent. This paper will examine Pedro of Coimbra and some of the men surrounding him during his political career (c. 1416 to 1449), in particular those employed as «diplomats» in foreign service. It will trace three different stages in Pedro's trajectory - as a prince in the making, as the king's counsellor, and finally as regent of the Portuguese kingdom - in order to question the extent to which a leading magnate of the fifteenth century was able to project his political influence in tandem with, or in reaction to, royal power. Ultimately, the paper highlights the co-existence, and indeed the overlap, between royal and non-royal diplomatic ambitions and the strains and challenges that it caused in the politics and diplomacy of Portugal in this period.

Keywords: Diplomacy; Political culture; Aristocracy; Medieval Portugal; Sovereignty. 


\section{ARTICLE}

Pedro of Avis has unanimously been considered a determined and able politician, whose public responsibilities gradually became associated with his dynasty's projection abroad. The second surviving son of João I of Portugal and his queen, Philippa of Lancaster, he was knighted and made duke of Coimbra at the age of twenty-two in 1415, in the wake of the Portuguese conquest of Ceuta. Second in the line to the throne, Pedro's political role spread increasingly throughout the successive reigns of three close relatives: that of his father, João, of his eldest brother, Duarte, and finally of his nephew Afonso V. During Afonso's minority, Pedro would rise to regent of the realm, a position he occupied for a period of approximately ten years starting in late $1438^{1}$. Pedro's governance and swelling political power as the head of the royal council, while acting on behalf of young Afonso, are known to have attracted resentment from competing magnates within the Portuguese court. Amidst allegations of lese-majesty and of favouring his own, Pedro would meet a bitter end in the field of battle in spring 1449 at the hands of his detractors, who had apparently manipulated the king into disowning the regent. The majority of Pedro's court followers and civil servants, previously employed in the regency's administration, were subsequently banned from royal service. Pedro of Coimbra's political ascendancy was indeed noteworthy, but the degree of his intervention in diplomacy is, I think, to be especially singled out. As will be seen, his bearing on Portuguese diplomatic transactions was

1 BARREIRA, C.F, and SEIXAS, M.M. (eds), D. Duarte e a sua época. Arte, cultura, poder e espiritualidade, Lisbon, 2014, GOMES, S.A., D. Afonso V, Rio de Mouro, 2005, and MORENO, H.B., and FREITAS, I.V. de, A corte de Afonso V: O tempo e os homens, Gijón, 2006, are helpful in framing the courtly and political settings of Pedro of Coimbra's career. More specific monographies on Pedro include: CORREIA, M.S., As viagens do Infante D. Pedro, Lisbon, 2000; GONÇALVES, J., O Infante D. Pedro, as "Sete Partidas» e a génese dos Descobrimentos, Lisbon, 1955; LIMA, D.M.X. de, O Infante D. Pedro e as alianças externas de Portugal (1425-1449) (unpublished MA dissertation), Niterói, Universidade Federal Fluminense, 2012; MARQUES, A.P., A maldição da memória do Infante Dom Pedro e as origens dos Descobrimentos portugueses, Figueira da Foz, 1994; MORENO, H.B., A Batalha de Alfarrobeira: Antecedentes e significado histórico, Lourenço Marques, 1973 (offprint of Revista de Ciências do Homem da Universidade de Lourenço Marques, $2^{\text {nd }}$ series, vol. 4); MORENO, H.B., O Infante D. Pedro, duque de Coimbra, Porto, 1997; and SCARLATTI, L., Os Homens de Alfarrobeira, Lisbon, 1980, complemented by Biblos, 69 (1993), a special issue collecting the Actas do congresso comemorativo do 6..$^{\circ}$ centenário do Infante D. Pedro: 25 a 27 de Novembro de 1992. The most insightful English overview of the regency is probably SOUSA, A. de, "The Iberian Peninsula: Portugal», in ALLMAND, C. (ed.), New Cambridge Medieval History, vol. 7 [c.1415-c.1500], Cambridge, 1998, pp. 627-44, complemented by ROGERS, F.M., The Travels of the Infante Dom Pedro of Portugal, Cambridge (MA), 1961. 
considerable, as it was consistently present even before the period of his regency.

It is the aim of this article to think about the nature of political representation in late medieval diplomacy in view of the part played in Portuguese diplomatic exchanges by the duke of Coimbra and his entourage during the first half of the fifteenth century. Some limitations to this approach exist, however, and they need highlighting. Even when referring to as relatively recent a context as this, the term «national» can be misleading. It can perhaps be made sense of collectively, around the already discernible state structures of most European polities alongside the agendas adopted by sovereign governments, and monarchies in particular (Portugal clearly among them $)^{2}$. Caution is also needed when considering "public» versus «private» spheres of political action, with whatever boundaries may have existed between the two. For our purposes, the former will be taken simply to mean a policy enacted in the interests of the common good - which is to say, by sovereign order on the consultation or advice of other political actors, as long as communally sanctioned - and the means and the agents used to carry it through. Such was the guiding principle of royal governance shared by all the better-established monarchies of the later middle ages, with the king - according to thinkers like Nicole Oresme — standing as «the most public person» in the kingdom ${ }^{3}$. But it should equally be said that as we know increasingly more about the circumstances surrounding the diplomatic interventions of actors beyond central power, be they local governments, wealthy burgesses (single-handedly or in coalition), or indeed, the high-born like Pedro of Coimbra, it too becomes clearer that for this period the private/ public divide is an ambivalent, even factitious, one to an extent; too clean-cut a distinction would be doubtful and unlikely to hold ground ${ }^{4}$.

2 Recently, FREITAS, J.A.G. de, O Estado em Portugal (séculos XII-XV): Modernidades medievais, Lisbon, 2011, pp. 40-41, but consider the remarks in BLOCKMANS, W., «Citizens and their Rulers», in BLOCKMANS, W., HOLENSTEIN, A., and MATHIEU, J. (with SCHLÄPPI, D.) (eds.), Empowering Interactions: Political Cultures and the Emergence of the State in Europe, 1300-1900, Aldershot, 2009, pp. 281-291, especially from p. 284 onwards.

3 Cited in HARDING, A., Medieval Law and the Foundations of the State, Oxford and New York, 2002, p. 274.

4 For instance, see the comments in HAMILTON, K., and LANGHORNE, R., The Practice of Diplomacy: Its Evolution, Theory and Practice, London and New York, 2011, p. 31 ff., and PÉQUIGNOT, S., «Europäische Diplomatie im Spätmittelalter: Ein historiographischer Überblick», Zeitschrift für Historische Forschung, 39/1 (2012), pp. 65-95 (p. 76), besides a growing repertoire of more closely directed studies, some of which (dealing mostly with northern Europe and commercial diplomacy) can be mentioned for their contribution to aspects of this discussion: FUDGE, J.D., Cargoes, 
In turn, even if this was not yet the period to be speaking of fully professional «diplomats» in general (and indeed of «diplomacy» in the modern understanding of the word), it should not be taken to mean that the agents of external representation and negotiation lacked preparation or direction. Far from it, a great many of them were perfectly and individually skilled, an indication of the growing subtlety by which relationships between foreign entities were sustained ${ }^{5}$. As will become apparent, the men in Pedro of Coimbra's seigneurial affinity were often to be found in diplomatic employment, but not always do they seem to be acting primarily on the duke's private business. In fact, a number of his followers appear at times to have been engaged in diplomacy as the representatives of the Portuguese king. This poses an important question for any discussion on the conception and the operational aspect of diplomacy as part and parcel of the governmental structures of the later middle ages: how «royal», after all, were royal diplomacies, in some cases at least? What follows suggests that the rationale behind royal diplomacy-making did not necessarily have to pivot around a well-defined pool of servants in the king's orbit and therefore directly in the regnal state's employment. On the contrary, resources drawn from both sovereign and non-sovereign powers could be, and indeed were, used variously to advance either national or private agendas - and quite likely they were used also to advance both kinds of interests concurrently.

Pedro of Coimbra is one such case of involvement in diplomacy at the baronial as well as the regnal level, and this matter will be considered by looking at the role that he and his entourage played in diplomatic exchanges consecutively across three periods. The first period, up to 1428 , comprises

Embargoes and Emissaries: The Commercial and Political Interaction of England and the German Hanse, 1450-1510, Toronto and London, 1995; HUFFMAN, J.P., The Social Politics of Medieval Diplomacy. Anglo-German Relations (1066-1307), Ann Arbor, 2000; JENKS, S., England, die Hanse und Preußen. Handel und Diplomatie, 1377-1474, Cologne and Vienna, 3 vols, 1992 (vol. 2); LLOYD, T.H., England and the German Hanse, 1157-1611: A Study of their Trade and Commercial Diplomacy, Cambridge, 1991; along with the essays, by Michel Bochaca, Louis Sicking, and others, included in SOLÓRZANO TELECHEA, J., ARÍZAGA BOLUMBURU, B., and SICKING, L. (eds.), Diplomacia, comercio y navegación entre las ciudades medievales de la Europa atlántica, Logroño (forthcoming this year).

5 PÉQUIGNOT, «Europäische Diplomatie»; LAZZARINI, I., «Renaissance Diplomacy», in GAMBERINI, A., and LAZZARINI, I., The Italian Renaissance State, Cambridge, 2012, pp. 425-443 (pp. 430-432); and the levelling remarks of Riccardo Fubini on «the marked spirit of professionalism displayed by diplomats» in Florence and elsewhere in Italy: FUBINI, R., «Diplomacy and Government in the Italian City-States of the Fifteenth Century (Florence and Venice)», in FRIGO, D., Politics and Diplomacy in Early Modern Italy (transl. A. Belton), Cambridge, 2000, pp. 25-48 (p. 26). 
Pedro's initial forays into political administration and representation abroad; the decade between 1428 and 1438 corresponds to a time when his public role was confined to membership of the royal council; and the years 14381449, during most of which Pedro exerted royal prerogative as regent for Afonso V. Each phase may be examined separately according to one varying element, Pedro's changing situation in the polity.

\section{ASPIRING POLITICIAN}

Pedro was personally engaged in diplomatic activity from a relatively early stage in his career. At about twenty-three years of age, he was represented at the council of Constance by his household administrator (governador*), Álvaro Gonçalves de Ataíde ${ }^{6}$. This capitalised on the exploits of the recent Portuguese crusading and the role that the prince and his siblings, the other infantes, played in it ${ }^{7}$. Pedro's legation to Constance created much interest, as in 1418 King Sigismund, later Roman emperor, offered Pedro the march of Treviso, in the region of Veneto, topped with 20,000 ducats annually were he to claim it in person ${ }^{8}$. The infante's own literary production shows his interest in the theoretical side of politics, and it is possible that he may have deliberately studied in preparation for what would become his grand tour of Europe, between 1425 and 1428. This started in England, where on 9 December 1425 he commemorated his thirty-third birthday, and took him to Burgundy, possibly Denmark, the Germanic lands, and Wallachia, from where

6 MARQUES, A maldição da memória, p. 530.

7 CRUZ, A., "Como El-Rey emuiou noteficar ho boom aqueeçimento da conquista de Ceuta», in Laços Históricos-Militares Luso-Magrebinos. Perspectivas de Valorização [V.A.], Lisbon, 2002, pp. 79-91.

8 ROGERS, The Travels of the Infante, pp. 9-16, argued that it was the knight-poet Oswald von Wolkenstein, who was among the Ceuta crusaders in 1415, who established the connection between the two men.

9 Yet, there is no sound evidence that «Pedro must have followed European politics very closely, especially Sigismund's relations with Venice and Bohemia» (ROGERS, The Travels of the Infante, p. 22). On Pedro's writings see among others SIMÕES, M., «Os textos didácticos da "Geração de Avis" », in CASTRO, F.L. de, História da Literatura Portuguesa. Vol. 1: Das origens ao Cancioneiro Geral, Lisbon, 2001, pp. 389-410, BUESCU, A.I., «Livros e livrarias de reis e de príncipes entre os séculos XV e XVI. Algumas notas», eHumanista, 8 (2007), pp. 143-70, as well as SOARES, N.C., «A Virtuosa Benfeitoria, primeiro tratado de educação de príncipes em português», Biblos, 69 (1993), pp. 289-314, FONSECA, J.A. da, «A Virtuosa Benfeitoria e o pensamento político do Infante D. Pedro», Biblos, 69 (1993), pp. 227-250, MATOS, M.C. de, "O Infante D. Pedro, a versão do De officiis e outras preocupações ciceronianas no Ocidente Europeu no século XV», Biblos, 69 (1993), pp. 315-341, and OSÓRIO, J.A., «A prosa do Infante D. Pedro. A propósito do Livro dos Ofícios», Biblos, 69 (1993), pp. 107-127. 
he, alongside Sigismund, fought the Turks over the next two years. Pedro's slow return, calling at Rome to see Pope Martin V, covered several Italian cities, the Crown of Aragon (marrying Elisabet d'Urgell, the heiress of Jaume II, count of Urgell and once the governor general of Aragon), and Castile ${ }^{10}$.

The heavy financial investment in this journey, demonstrated by a later computation from the Portuguese fazenda (the royal exchequer), compiled $c$. 1473, reinforces the idea of Pedro's voyage, which was paid certainly in part by the crown, being a carefully planned affair ${ }^{11}$. There can be little doubt as to its objectives being political ${ }^{12}$. All of those hosting the duke's entourage were either existing political and/or economic partners of the Portuguese, or in the position of strengthening relations. "The son of the king of Portugal», as he is referred to in most contemporary accounts, had entered into direct contact with these partners, Europe's main powers, and become personally acquainted with their leaders. It cannot be an accident that this Portuguese convoy took an Atlantic rather than a Mediterranean route. One might have expected Pedro and his company to pay their respects to the pontiff at the earliest possible moment in their trip, especially since they all were men going on crusade, and therefore in a position to receive indulgences. Yet, rather than taking the shortest way to the papal curia, Pedro's first stop was England, followed by Burgundy, while steering clear of territories belonging to the French crown, echoing the political divide which the Hundred Years' War had imposed. It looks as though it was necessary for Pedro to test the waters diplomatically, by initially paying compliments to Portugal's prime political and economic partners, in order to set the tone for the rest of the trip - a trip that deserves to be considered a focal event in explaining the outreach of some of Pedro and his diplomatic network's later political moves.

\section{ROYAL ADVISER}

For ten years after his return, it was a well-acquainted and widely-travelled Pedro who served in the royal council, advising the Portuguese kings -

$\overline{10}$ I follow the account in ROGERS, The Travels of the Infante Dom Pedro (ch. 3), by far the most complete concerning Pedro's political journey.

11 Several sixteenth-century copies of this document survive, with minor differences (for example, Lisbon, Biblioteca da Ajuda MS. 50-V-20, ff. 138-39 v.); see also FARO, J., Receitas e despesas da fazenda real de 1384 a 1481 (Subsídios documentais), Lisbon, 1965, p. 67. For criticism, MARQUES, A.H.O., Portugal na crise dos séculos XIV e XV, Lisbon, 1987, p 329, n. 3.

12 For conflicting interpretations of Pedro's voyage, see ANDRADE, A.A.B. de, Mundos novos do Mundo: Panorama da difusão, pela Europa, de notícias dos Descobrimentos geográficos portugueses, vol.1, Lisbon, 1972, pp. 17-22. 
firstly, João I and his deputy-in-chief, João's eldest son Duarte, and from 1433 the latter alone. It was during this period and until 1433, that most crown affairs were managed by the royal heir, who, according to a recent biographer, despite intervening in a legislative capacity, seems not to have acted so much as a political leader. Instead, Duarte's knee was bent before João I's auctoritas, since the king kept his lucidity until late in life ${ }^{13}$. For these reasons, it is not easy to tell who exactly was behind the royal wheel in the late 1420s and early 1430s. Besides it has been suggested that political differences separated Pedro and his father, with historians arguing that before departing to Europe in 1425 Pedro had been disillusioned by the conduct of government ${ }^{14}$. Duarte, however, was interested in his brother's opinions, as is shown by the correspondence exchanged between the two during Pedro's journey. Pedro's conceptions of governance, expounded in his moral and political treatise A Virtuosa Benfeitoria, were clear ${ }^{15}$. As Rita Costa Gomes has put it, these were a «defence of a social cohesion obtained through the circulation of gifts and of the ideal of a royal freedom released from the formal obligation of quid pro quo» ${ }^{16}$. The fact that Pedro believed strongly that the managing of clientele and personal connections were key political tools is significant, and it will help us frame the activities of his personnel.

Pedro of Coimbra liaised with important personages about Portuguese matters even before his return to Portugal. In August 1427, when he was with Sigismund on crusade in Wallachia, Alfons V of Aragon (whom Pedro was soon to meet in person in Valencia) sought his favour in recommending to Sigismund the services of the Aragonese chamberlain. Alfons also wished to inform Pedro of his sister's engagement to Pedro's brother Duarte ${ }^{17}$. This might suggest Pedro's prior involvement in these talks. About one year later, the duke surfaced in Anglo-Portuguese royal affairs, once again discreetly. A hitherto unknown document from the English exchequer, dating from July 1428 , registers that «mounte Maior herauld nadgairs a nous [fut] envoiee

13 By 1415 Duarte had been given charge of most aspects of governance: DUARTE, L.M., D. Duarte: Requiem por um Rei Triste, Rio de Mouro, 2005, chs 5-7 (especially pp. 49, 62-6) expresses the difficulties posed by limited evidence existing from the long period of Duarte's housekeeping.

14 DUARTE, D. Duarte, pp. 79, 86, 117.

15 These included reformist ideas inspired by foreign institutions such as the University of Oxford and the guilds in Bruges: see King Duarte's Leal Conselheiro, in PIEL, J.M. (ed.), Lisbon, 1942, ch. 14.

16 GOMES, R.C., The Making of a Court Society: Kings and Nobles in Late Medieval Portugal (transl. A. Aiken), Cambridge, 2003, p. 425.

17 ALMEIDA, M.L. de, BROCHADO, I.F.C., and DINIS, A.J.D. (eds), Monumenta Henricina, vol. 3 [1421-1431], Coimbra, 1961, p. 163. 
depar nostre treschier et tresame frere le roy de Portugale en soun message», for which this herald was to be rewarded ${ }^{18}$. Although he is designated as the carrier of letters from the king of Portugal, we can safely assume that this messenger was Pedro's servant. King João I's own heralds were typically named after towns directly under the crown, such as «Lisboa»; the name «mounte Maior» certainly referring to one of Pedro's greatest lordships, the town of Montemor-o-Velho ${ }^{19}$. A princely, rather than a royal (which is to say, a non-private), herald had thus been chosen for this mission. Montemor had been sent with royal business for João, but either Pedro, who was still on his European journey, interfered directly or the Portuguese crown chose to capitalise on the links which had been established at Henry VI's court by him previously. These ties are further emphasised by documentary references, within the month, to the recent installation as a Garter knight of the «duc de Quymbre $»^{20}$. Montemor Herald would also feature in Portuguese exchanges with Burgundy. While in 1435 he appears in the Burgundian sources clearly in Pedro's command, three years later he would be called «Montmajour, herault du roy de Portugal», which only accentuates the dichotomy - or perhaps better said, the fuzziness - between the representation of sovereign and non-sovereign princely powers ${ }^{21}$.

The duke of Coimbra and his clientele also continue to appear in Anglo-Portuguese politics, operating within the king's own sphere, into the reign of Duarte. The envoy sent in 1434 to announce Duarte's accession,

18 TNA, E 404/54/322

19 For officers of arms in Portugal, LIMA, J.P.A. e, Armas de Portugal: Origem, evolução, significado, Lisbon, 1998, p. 143 ff., LIMA, J.P.A. e, «Oficiais de Armas em Portugal nos séculos XIV e XV», Genealogica \& Heraldica: Actas do $17 .^{\circ}$ Congresso Internacional das Ciências Genealógica e Heráldica, Lisbon, 1989, pp. 309-47, and ANSWAARDEN, R. van, «Dois arautos e um harpista. As missões diplomáticas de D. João I à Holanda», História, vol. 26/27 (1980), pp. 44-59. On Pedro's estates, the most comprehensive study still is COELHO, M.H.C., O Baixo Mondego nos Finais da Idade Média (Estudo de História Rural), 2 vols, Coimbra, 1983.

20 TNA, E 404/44/329, of 1 July (also in RYMER, T. (ed.), Foedera, conventiones, literae, et cujuscunque generis acta publica inter reges Anglice et alios, 20 vols, London, 170435, vol. 10, p. 405). Montemor could also be traced in England in 1420, according to ADAM-EVEN, P., and SÃO PAYO [Marquês de], «Études d'héraldique médiévale (Armoiries portugaises dans les armoriaux français du moyen-âge)», Armas e Troféus, $2^{\text {nd }}$ series (1960), pp. 46-61, p. 51, and LIMA, «Oficiais de Armas em Portugal», p. 325.

$21 \quad$ PAVIOT, J. (ed.), Portugal et Bourgogne au XV siècle (1384-1482): Recueil de documents extraits des archives bourguignonnes, Lisbon and Paris, 1995, pp. 253 (doc. 166), 254 (doc. 168) and 289 (doc. 218, quoted). The exact aim of these visits remains unknown. LIMA, «Oficiais de Armas em Portugal», p. 327, notes that Montemor had also called at the Burgundian court before this, in 1430 . 
João Rodrigues Trigueiro, does not seem to bear any particular connection with Pedro ${ }^{22}$. Yet, we know that in March 1436 a certain «Lowys Dazavedo chivaler du royaume du Portugale» was in England, after having delivered letters from the Portuguese king ${ }^{23}$. His mission was far more delicate than Trigueiro's had been. According to Portuguese records, in November 1435 «Luys d'Azevedo cavaleiro da cassa do ifante Dom Pedro» was about to be sent to England on royal business, namely with a list of grievances presented by Duarte ${ }^{24}$. This «knight of the Infante Dom Pedro's household» was also to procure from Henry VI his ratification of the Anglo-Portuguese alliance, which Henry had been putting off. He was successful in obtaining this as well as a favourable reaction to the complaints he had presented on behalf of the king of Portugal. Azevedo and his kinsmen would be generously rewarded by writ from the English royal council ${ }^{25}$. Around the same time, in May 1436, orders were given to convey Garter robes to King Duarte, who recently had been admitted into the order. Robes were also to be sent «au Don Pedro, frere du dit roy» ${ }^{26}$. Azevedo's political achievements in England for the Portuguese crown, as well as the consideration which he and his two masters were shown during a period of uncertainty in Anglo-Portuguese relations, demonstrate just how wise the choice of one of Pedro's retainers as a royal envoy had been. Conversely, the use of Pedro's personal network in diplomacy surely functioned as a means to strengthen his grip as a leading magnate in the Portuguese power structure.

\section{REGENT OF THE REALM}

We move on from a period when Pedro's role in government had supposedly been confined to membership of the royal council, to a period during which a sovereign authority might be called upon based on his position as regent. Duarte's premature death in September 1438, leaving his son and heir Afonso, a boy of six, produced a political crisis. Duarte's will had specified Leonor of Aragon as Afonso's tutor and regent of the realm. Parliament, however, decided to co-appoint Pedro in December that year. Increasing tensions and criticism ultimately cast the queen-mother from power, and from December 1439 Pedro ruled Portugal as the sole regent for King Afonso V, who having

\footnotetext{
22 He was «scutifer de domo [...] regis Portugalie et Algarbii»: RYMER, Foedera, vol. 10, p. 598; TNA, E 404/51/128.

TNA, E 404/52/220.

24 AHMCML, «Chancelaria de D. Duarte e de D. Afonso V», Liv. 2, doc. 14.

25 RYMER, Foedera, vol. 10, p. 641.

26 RYMER, Foedera, vol. 10, pp. 639-40, 641.
} 
come of age in January 1446 entrusted his uncle with maintaining the regency for longer than originally stated. The mandate would end in July 1448, however, as Pedro came under mounting accusations of misgovernment. Shortly afterwards he was banished from the royal court, only to die in battle defending his honour, in May 1449.

While, under Pedro's ten-year rule, the structures of government in Portugal progressively became more centralised, it appears that his standing in England was also reinforced ${ }^{27}$. Henry VI's own government had acknowledged the joint regency of Leonor and Pedro: in September 1439, the two signed, on behalf of Afonso V, the ratification of the treaty with England. But less than three months later (on 31 December), it was to Pedro alone that a letter was addressed from Westminster, which was meant to reinforce a commercial petition made on the same day to Pedro's nephew the king, concerning the wellbeing of English subjects ${ }^{28}$. The regent's political weight was certainly being played up in England, and this could not be clearer than from a mandate issued in August 1445, at the height of his rule, by the English government, which granted him the authority to arrange for a peace settlement between England and Castile, calling on the regent's prudence, reason and experience. Henry VI and his council were therefore placing in the hands of Henry's "cousin le regent» the fate of a highly anticipated treaty of perpetual friendship with Juan II of Castile. Pedro was not expected simply to mediate: he was to negotiate, sign, and swear the treaty on Henry's behalf ${ }^{29}$.

The English government must have been fully conscious that Pedro was a keen supporter of the cause of Juan and his favourite, Don Álvaro de Luna, against the princes of Aragon. Following Castilian pleas for help, in May 1445 the regent's son and constable of Portugal, also named Pedro, had led an army of around 2,500 into Castile. The Portuguese army missed the battle of Olmedo (19 May), where the Aragonese forces were defeated. Condestável Pedro was nonetheless met with Juan's gratitude, withdrawing only in the following July or August ${ }^{30}$. The political support given by the

27 This centralising policy is discussed most informatively in SOUSA, «The Iberian Peninsula: Portugal», pp. 639-40, and MORENO, H.B., «O Infante D. Pedro, da Regência a Alfarrobeira», Biblos, 60 (1993), pp. 3-13 (especially pp. 9-10).

28 RYMER, Foedera, vol. 10, p. 751 (TNA, E 28/63/51: the date is mistaken in FERGUSON, J., English Diplomacy, 1422-1461, Oxford, 1972, p. 54, n. 4), p. 752. It is vaguely possible that the English government had just been informed of the decision, taken earlier that month, of the Portuguese cortes to appoint Pedro as the sole regent.

29 RYMER, Foedera, vol. 11, pp. 96-97.

30 MORENO, A Batalha de Alfarrobeira, pp. 224-34. The bibliography on Castilian high politics during Juan II is nothing but immense, but gateways into this complex topic 
Portuguese regency to the Castilian monarchy had direct, positive impact on Anglo-Castilian relations ${ }^{31}$.

It certainly is no coincidence that on exactly the same day the English issued the regent of Portugal with their mandate to sign an agreement with Castile, Álvaro Vasques de Almada, the most outstanding of Pedro's followers, was granted an annuity from the English exchequer. It is impressive that this award, worth one hundred marks per year, should be given to Álvaro on top of his being made count of Avranches (Normandy), and in addition to his elevation into the Order of the Garter ${ }^{32}$. English patronage of this individual at this time (it was probably he who carried to Portugal the important mandate from Henry VI) was certainly aimed at flattering Pedro, with internal struggles in Castile under control - and Pedro enjoying added influence on the Castilian government, thanks to which he was also in a position to intercede for the English.

But Álvaro Vasques de Almada was not alone among the regent's affinity in becoming involved in external politics. We know that Pedro dealt out public offices in Portugal extensively to his followers ${ }^{33}$; it is only natural that his political and diplomatic networks abroad were similarly expanded. Following what had become standard practice in fifteenthcentury Europe, he seems to have relied heavily on officers of arms, just like Montemor Herald, to act as diplomatic agents. By now, heralds and other officers of arms had become specialists in public relations, besides enjoying additional safety and immunity from their rank, which made them particularly appropriate for diplomatic tasks ${ }^{34}$. Famously, William Bruges,

are PORRAS ARBOLEDAS, P.A., Juan II, rey de Castilla y León (1406-1454), Gijón, 2009, SUÁREZ FERNÁNDEZ, L, Nobleza y monarquía: entendimiento y rivalidad. El proceso de construcción de la Corona española, Madrid, 2003, or, in English, ROUND, N., The Greatest Man Uncrowned: A Study of the Fall of Don Alvaro de Luna, London, 1986.

31 These interconnections are addressed in GOODMAN, A., and MORGAN, D., "The Yorkist Claim to the Throne of Castile», Journal of Medieval History, 11 (1985), pp. 61-9 (pp. 65-66).

32 RYMER, Foedera, vol. 11, pp. 95-96; TNA, E 404/61/271. On his nomination to the order, BELTZ, G.F., Memorials of the Most Noble Order of the Garter, from its Foundation to the Present Time, London, 1841, p. clx.

33 MORENO, A Batalha de Alfarrobeira, pp. 264-319.

34 Current scholarship has been particularly keen to highlight this: see the essays collected in SCHNERB, B., Le héraut, figure européene (XIVE-XVI siècle) [special issue of Revue du Nord, vol. 88, (nrs 366-367)], 2006, now updated by BOCK, N., «Herolde im Reich des späten Mittelalters. Forschungsstand und Perspektiven», Francia - Forschungen zur westeuropäischen Geschichte, vol. 37 (2010), pp. 259-82, and HILTMANN, T., «Herolde und die Kommunikation zwischen den Höfen in Europa (14. bis 16. Jahrhundert)», in PARAVICINI, W., and WETTLAUFER, J., Vorbild-Austausch-Konkurrenz: Höfe und Residenzen in der gegenseitigen Wahrnehmung, Ostfildern, 2010, pp. 37-63. 
perhaps «the first herald to specialize in diplomatic work», was employed regularly, from Brittany to Italy, from Scotland to the Iberian Peninsula, often as the principal agent ${ }^{35}$. Notwithstanding Pedro's attraction for all things chivalrous and the fact that the employment of heralds in diplomacy had now become generalised, it seems probable that he elected to use officers of arms principaly because of their growing professionalisation in diplomacy in the state's service - which distinguished them from gentlefolk, merchants, or scholars, who were often drawn from «mixed» environments and who might perhaps escape governmental control more easily ${ }^{36}$. Pedro's style of governance, in which a skilled and loyal ducal clientele was used to reinforce the central power of the state, may also have been projected in how he chose to conduct his external affairs: heralds were bound to him, as magnate, through personal affinity, and to him, as statesman, from the functions they were made to perform. Some examples can be cited in this regard.

In autumn 1444, Bruges, the Garter King of Arms, was sent to Aragon and Portugal in order to deliver Garter robes respectively to King Alfons $\mathrm{V}$ and Infante Henrique ${ }^{37}$. His partner on this voyage was a Portuguese pursuivant, whom the sources name «Balence». Balence could hardly stand for anything other than «balança», the Portuguese word for scales. The scales were Pedro's personal badge, which he is known to have used in official transactions. In 1440, he detailed which seals should be taken as authentic in documents issued in his name, among them a signet ring consisting of his device of the scales $^{38}$. It was thus «Passavante Balança», as he would have been known in his homeland, whom we find in England in 1444, presumably at the regent's service. Such was the last of several recorded visits he made to the English

35 LONDON, H.S., The Life of William Bruges, the First Garter King of Arms, London, 1970, pp. 20-2 (and examples in Appendix 1); FERGUSON, English Diplomacy, pp. 189,196

36 Neither to be forgotten were each herald's individual qualities, as noted in MATTINGLY, G., Renaissance Diplomacy, London, 1963, p. 32. For Pedro's chivalry, FARIA, T.V. de, «Pela "Santa Garrotea": Ofício cavaleiresco nas vésperas de Alfarrobeira», XIV Colóquio de História Militar: Portugal e os Conflitos Militares Internacionais (Lisboa, 22-25 Nov. 2004). Actas [V.A.], vol. 2, Lisbon, 2005, pp. 61-86.

37 LONDON, H.S., The Life of William Bruges, p. 22, citing «R.G. I, 338». I was unable to consult this source.

38 Cited in COELHO, M.H.C., «O Infante D. Pedro, Duque de Coimbra», Biblos, 69 (1993), pp. 15-57, pp. 51-2, n. 157. On Pedro's badge, AVELAR, H. de, and TÁVORA, F., «As Empresas dos Príncipes da Casa de Avis», XVII Exposição Europeia de Arte, Ciência e Cultura. Os Descobrimentos Portugueses e a Europa do Renascimento. Convento da Madre de Deus - Catálogo, Lisbon, 1983, pp. 227-33, p. 228. 
court, all in successive years between 1442 and $1444^{39}$. This suggests that Balança may well have been the most travelled among Portuguese diplomatic envoys during the regency period, certainly to England but very likely elsewhere too. He seems to have moved over to dealing mostly with the Duchy of Burgundy, where he could be found in 1446 and 1449, on both occasions as the "poursuivant d'armes de l'infant dom Pierre de Portugal», and possibly also in $1447^{40}$. It remains to be confirmed whether another character, Pursuivant Désir - his title being the same as Pedro's personal motto, which complemented his device of the scales — sided with Balança as a representative of the infante (or was it the regent) to the duchy. Désir is recorded as having been there in $1446^{41}$.

Prince Pedro's personal servants were sent off on governmental missions every so often. But whichever boundaries still stood between the public and the private remits become all the more confused since Pedro seems also to have used royal heralds on his own account, namely at a time when his political power in Portugal had started to wane. The two highest-ranking Portuguese officers of arms were both sent on missions by him: Rei-de-Armas Portugal in 1445 and Algarve in $1448^{42}$. The latter had certainly been trusted «with divers erandes frome oure righte trusty and righte welbeloved cousin $\mathrm{Pe}[\mathrm{dro}]$ regent of Portugale and hath entendid here upon us for his answere a longe tyme to his charge and grete coste». It was uncommon for a king of arms to be identified in official sources as an emissary from a regent figure instead of the nominal sovereign ruler, and it is plausible that the reason the English answer would come in so late had to do with the fact that, since about 1446, Pedro's position in Portugal had grown significantly weaker. Besides, even a national office, so to speak, such as that of king of arms might be politicised, and it is not impossible that Rei-de-Armas Algarve was a supporter of Pedro at a particular level. He, for example, received from the regent generous grants of land in 1441 and again in $1442^{43}$. It does not

39 He was twice rewarded and about to leave the country, in July 1442 and October 1443: TNA, E 403/745, m. 12, E 404/60/64.

40 PAVIOT, Portugal et Bourgogne, pp. 367 (doc. 285) and 376 (doc. 300), both misread for «Valença»; LIMA «Oficiais de Armas em Portugal», pp. 330-31.

${ }^{41}$ PAVIOT, Portugal et Bourgogne, p. 365 (doc. 282). LIMA, J.P.A, and SANTOS, M.A.P., «Quem foi Gonçalo Caldeira: testemunhos para uma análise de funções políticas na corte portuguesa quatrocentista — de D. João I a D. Afonso V», Revista da Faculdade de Letras -Ciências e Técnicas do Património, 2 (2003), pp. 335-46 (pp. 343-44).

42 LIMA «Oficiais de Armas em Portugal», p. 330; TNA, E 404/64/229. An unspecified officer of arms was used in 1446 (TNA, E 403/772, m. 4).

43 According to NORTON, M.A., A Heráldica em Portugal. Vol. 1: Raízes, simbologias e expressões histórico-culturais, Lisbon, 2004, p. 165; and see TT, «Chancelaria de D. Afonso V», Liv. 23, f. 59. 
seem out of place to suggest that Pedro was using the crown's officers of arms who were simultaneously his partisans to make a point of his control over government. If Algarve had indeed been charged with finding support for the regency in England in 1448, his achievements proved insufficient: Pedro soon fell victim to the contestation roaring at court and was ushered away from office.

\section{CONCLUSION}

Further investigation, particularly of a comparative nature, on the logic and implementation of diplomacy across medieval Europe would help clarify matters in areas where the available documentation for Portugal is too scarce. There is still work to be done on the issue of conflicting jurisdictions between masters, and therefore of having to determine the legal, and indeed political, responsibilities in mixed diplomatic environments such as that discussed. We also need to know more about the exact conditions of service of those purpose-trained, highly-specialised officials attached to the crown service during this period - for instance, whether people like the experienced officers of arms used in royal diplomacy were able, or even expected, to continue serving throughout successive, and sometimes dramatically opposed, political regimes. Had someone like the Algarve King of Arms (whose personal identity, as with that of most medieval heralds, remains concealed) kept their post after the painstaking eradication of Pedro of Coimbra's affinity from public office in the late 1440s, it might have told us something of the rationale behind the running of state institutions and the employment of the skilled non-privileged.

These reservations notwithstanding, several conclusions can be drawn from the foregoing analysis. The activities of Infante Pedro amount to a vigorous and politically influential dynamic in Portuguese diplomacy over several decades. It was the duke and his network who effectively handled much of the diplomatic traffic between the crown and its most prominent neighbours, clearly the more so after the European expedition of 1425-28. It is difficult to tell exactly how much of this reflected Pedro's personal policy and how much of it was aligned with the policies of Pedro's father João I, or his brother Duarte, and indeed the royal council during Pedro's own regency. Be this as it may, in all likelihood royal diplomacy in Portugal was regarded as something to be handed down for the non-ruling (partly) to manage. The extent to which the same could be said of other late medieval states and their approach to external relations would be well worth exploring: it cannot be stressed enough that the leading forces at the front of polities were not 
monolithic as far as diplomacy was concerned. Even in a state as centralised as fifteenth-century Portugal diplomacy allowed for a diffusion of power, both in how such power was apparently conceived of and the people exercising it in practice. The case of Pedro of Coimbra shows just how problematic this type of influence on royal foreign policy by a princely figure might be, especially if the specific interests at stake diverged from those of the crown or the community of the realm (for example, the regency's Castilian policy was hotly contested, and Portuguese relations with the English clearly lost force after Pedro's final defeat in 1449).

What is more, the actions of the duke of Coimbra as he fulfilled various roles in succession within the polity, taken together with the activity of the agents being used along the way, indicate the presence of a network of people that operated politically at the intersection of aristocratic and royal service. There remains no doubt that many of the agents more deeply involved in Portuguese royal diplomacy over the first half of the fifteenth century were at the same time the active members of a princely household - one which, to all intents and purposes, was separate from the king's. Drawn variously from the royal and the ducal courts, these men were therefore connected, sometimes concurrently, to the service of the crown and to the service of a non-sovereign princely power, with variable degrees of interaction existing between the two. These diplomatic agents, moreover, were pliable enough to operate in several political arenas, just like Montemor Herald did in Burgundy and England, on behalf of the king of Portugal as much as on behalf of his immediate lord. They demonstrate how useful officials in positions like theirs might have been at reinforcing royal politics, as much as they were key in propping up the interests of those with whom they were most closely affiliated. This argues strongly for the existence of what might be termed a diplomatic sub-system operating in tandem with royal government, whose real dimension is difficult to determine but whose actions had a direct and observable impact on the policy-making process. Such a system would have stood partly as one component of inter-state relations, while enjoying relative autonomy, as it relied on private or semi-private clienteles and networks. 